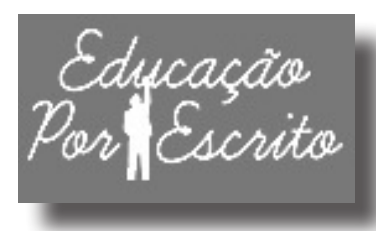

ARTIGO

\title{
Uma outra ambiência nas pesquisas educacionais: acerca do pesquisar com Deleuze e Guattari*
}

\author{
Another ambience in educacional research: study with Deleuze and Guattari
}

Christian Fernando Ribeiro Guimarães Vincia

\section{Editores \\ Maria Inês Côrte Vitoria PUCRS, RS, Brasil Pricila Kohls dos Santos PUCRS, RS, Brasil}

\section{Equipe Editorial}

Rosa Maria Rigo

PUCRS, RS, Brasil

\section{ISSN 2179-8435}

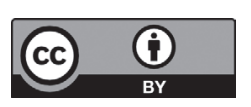

Este artigo está licenciado sob forma de uma licença Creative Commons Atribuição 4.0 Internacional, que permite uso irrestrito, distribuiçăo e reprodução seja corretamente citada http://creativecommons.org/licenses/by/4.0/deed.pt_BR

\section{RESUMO}

Este ensaio procura sondar certa especificidade do dispositivo conceitual elaborado por Gilles Deleuze, em parceria ou não com Félix Guattari. Partindo da pressuposição de que as noções deleuzeanas e deleuzeguattarianas, não obstante comportarem uma incitação às experimentações radicais de pensamento, possuem um lastro intelectivo que demanda certa prudência investigativa ou analítica por parte dos pesquisadores, propõe-se pensar como estes elementos - experimentação e exegese -, aparentemente antagônicos, convivem no interior do aparato conceitual de Deleuze e Guattari. Sugere-se também uma análise sobre quais as implicações dessa convivência para aqueles interessados em trabalhar com esses autores, mormente no campo educacional. A hipótese a ser experimentada é a da existência de uma pressuposição recíproca entre exegese e experimentação, vigorando no interior da filosofia da diferença, conforme nota-se alhures (referência omitida), o que, por sua vez, demanda por parte do pesquisador operar com aquilo que Luiz B. Orlandi (2000) denominou de composição elementar dos encontros. Essa composição exige a invenção de um par questão-problema singular, resultado do encontro com uma violenta urgência vital que impele um vivente a pensar. Concomitantemente, é capaz de conduzir a um processo de criação conceitual, único movimento capaz de propiciar novos modos de existência aptos a fazer frente àquela mesma urgência vital encontrada. Esse processo implica operar com outra concepção do que significa pensar, colocando experimentação e criação ao lado de compreensão e recognição. Justifica-se tal discussão, uma vez que, costumeiramente, tende-se, nas pesquisas, a operar com algumas noções elaboradas por Deleuze e/ou Deleuze-Guattari de maneira mecânica, transmutando o princípio plástico do conceitual deleuze-guattariano, seu lastro experimental, em uma espécie de fundamento metafísico, e ressaltando apenas

\footnotetext{
* Este texto é uma versão modificada e ampliada de comunicação apresentada no "VIII Colóquio Internacional de Filosofia e Educação: mundos que se tecem entre 'nosotros' - 0 ato de educar em uma língua ainda por ser escrita". Agradecimentos aos que participaram das discussões sobre o texto, bem como à Fapesp, por financiar este trabalho.

a Doutorando pela Faculdade de Educação da Universidade de São Paulo (FE-USP). Bolsista FAPESP. Integra o Coletivo de Pesquisadores sobre Educação e Relações de Poder - CoPERP.
} 
seu lastro intelectivo. A fim de evitar essa confusão, pretende-se apresentar a especificidade da relação questãoproblema-conceito. Busca-se discutir como essa tríade pode ser apreendida na noção deleuze-guattariana de conceito, atentando tanto para a sua definição formal quanto para a sua definição modal e ressaltando como o próprio Deleuze lidou em seu percurso intelectual com essas questões, sobretudo em seu trabalho conjunto com Félix Guattari. Por fim, buscando estabelecer uma interlocução com o campo educacional, procura-se pensar os modos como Deleuze e Guattari têm sido evocados e utilizados por muitos pesquisadores do campo educacional.

Palavras-chave: Gilles Deleuze; Félix Guattari; Conceito; Problema.

\section{ABSTRACT}

This essay will try to probe the specificity of the conceptual developed by Gilles Deleuze, in partnership or not with Felix Guattari. We argue that the deleuzeans and deleuze-guattarians notions nevertheless conduct an incitement to radical experiments of thought, have an exegetical ballast that requires some caution by the part of researchers interested in operating with the concepts developed by the authors. There would be, between exegesis and experimentation of the Deleuze and Guattari's conceptual apparatus, a reciprocal implication that would require the preparation of an elemental composition of the meetings by the researcher, as both Orlandi (2000) noted. This composition would involve the invention of a pair question-problem, as the result of a violent vital urgency that impel us to think, and, concomitantly, the invention of a unique concept, capable of providing a living new modes of existence able to stand up to that vital urgency. Understanding this relationship is necessary in that often we tend in our research to operate with some notions developed by Deleuze, in partnership or not with Guattari, mechanically, transmuting the plastic principle of deleuze-guattarian concept in a kind of metaphysical foundation. In order to avoid this confusion, we intend to present the specificity of the questions drawn up by Deleuze and Guattari, their relationship with the invention of some problems and how this presuppose the invention of a unique concept. Furthermore, we will seek to discuss how the French authors conceive a concept, considering his formal and his modal definition. Finally, we will explore a little the intellectual journey of Gilles Deleuze, mainly the result of its partnership with Felix Guattari, to understand the specific modes of experimentation of thought experienced by the author. Our intent is not to draw up a deleuzean research methodology or deleuze-guattarian, but understanding how these elements can, we believe, help researchers interested in the philosophy of difference by Deleuze and Guattari.

Keywords: Gilles Deleuze; Felix Guattari; Concept; Problem. 


\section{Introdução}

É inteligência minha haver sido muitas coisas em muitos lugares, para poder tornar-me um - para poder alcançar uma coisa. Por um tempo eu tive de ser também erudito.

FRIEDRICH NIETZSCHE

$\mathrm{O}$ que é o devir? O filósofo francês Gilles Deleuze consideraria uma tal questão, assim como outra qualquer envolvendo a famigerada construção o que é, como "particularmente estúpida" (DELEUZE, 1976, p. 86). Para o autor de Nietzsche e a filosofia, essas indagações, costumeiramente interessadas em buscar fundamentação metafísica para determinado objeto ou ente, careceriam de legitimidade ou, no mínimo, estariam mal colocadas. Não seriam legítimas, pois tais perguntas apenas visariam a validar um plano que transcende responsáveis por condicionar os modos de sentir e pensar determinado estado de coisas. Sendo assim, ao se perguntar o que é um cachorro, seguindo um exemplo banal fornecido por Vicent Descombes (1998) e análogo à indagação acerca do devir, depara-se sempre com certa ideia suprassensível enraizada no senso comum, qual seja: um mamífero quadrúpede da família dos canídeos, com pernas longas, pés anteriores com quatro dedos e posteriores com cinco, garras fortes e não retráteis, cauda longa e peluda etc. Diante dessa definição, normalmente transmutada pela doxa em conceito, cabe uma única possibilidade de investigação: dado um animal em particular, ele adequar-se-ia ou não à ideia que dele possuo? Em outros termos, esse cachorro que se apresenta a mim seria ou não verdadeiramente um cão?

Deleuze, retomando certas análises de Friedrich Nietzsche (2004), denunciaria um falso problema envolvendo as questões supramencionadas, pois perguntar se algo é aquilo que deveria ser não significa nada mais do reconhecer ou validar um ideal regulador de nosso espaço de experiência ou, em outros termos, fortalecer uma moral ${ }^{1}$. São, portanto, colocações em busca de fundamentos metafísicos, conforme diz o autor de Bergsonismo (2012), responsáveis por impedi que se criem as próprias problematizações ao imporem problemas totalmente acabados. Deleuze enxerga nessas imposições uma espécie de preconceito social:

\footnotetext{
1 Obviamente, no exemplo trabalhado por Descombes (1998) e aqui resgatado, não há maiores implicações morais em procurar saber se um cachorro é ou não é um verdadeiro cachorro. Contudo, deixando de lado esse exemplo banal, pode-se pensar em outros exemplos mais problemáticos: a justiça, por exemplo. Indagar se um ato ou se alguém é ou não é justo envolve um padrão de justiça. "Criado por quem?", indagaria Nietzsche. Quem quer essa justiça? Esse querer, imposto por um alhures, pode limitar a potência de agir de um vivente, preso a padrões estabelecidos por um suposto bom senso e partilhados pelo senso comum. Apresenta-se essa discussão de maneira um tanto sumária, pois são outros os objetivos deste trabalho. Entretanto, àqueles interessados no aprofundamento desse debate, indica-se Deleuze (1976; 2013).
} 
Esse preconceito é social (pois a sociedade, e a linguagem que dela transmite as palavras de ordem, "dão"nos problemas totalmente feitos, como que saídos de "cartões administrativos da cidade", e nos obrigam a "resolvê-los", deixando-nos uma delgada margem de liberdade). Mais ainda, o preconceito é infantil e escolar, pois o professor é quem "dá" os problemas, cabendo ao aluno a tarefa de descobrir-lhes a solução. Desse modo, somos mantidos em escravidão. A verdadeira liberdade está em um poder de decisão de constituição dos próprios problemas: esse poder, "semidivino", implica tanto o esvaecimento de falsos problemas quanto o surgimento criador de verdadeiros (DELEUZE, 2012, p. 11).

Constituir os próprios problemas, seguindo o argumento apresentado pelo filósofo francês, não é apenas praticar uma verdadeira liberdade de decisão, mas outro modo de pensar. O pensamento, para Deleuze, define-se antes pelo princípio plástico que comporta, e não por certa tendência natural em buscar validações metafísicas ao real. Em outros termos, pensar é criar ou inventar outros possíveis e nunca fundamentar um estado de coisas dado ou um real.

Desse modo, a legitimidade de uma questão fica atrelada antes às possibilidades de invenção de novos pontos de vista, aos problemas que a indagação inventa, e não necessariamente à sua capacidade de inquirir o quanto o real adapta-se ou não à ideia apriorística que dele se possui. Mas como produzir uma tal problematização? Uma saída, apontada já por Nietzsche em seu Ecce homo (2004), é deixar de perguntar se algo é, passando a tomar como questão como algo ou alguém se torna aquilo que é?

A força desse mote nietzschiano reside no abandono de todo e qualquer princípio regulador ou regra moral, sem apriorismo ou caminho a ser seguido, tampouco telos, o que envolve unicamente a aceitação incondicional das contingências, do jogo inerente ao viver. Sem apriorismos, as coisas tornam-se aquilo que são por conta de fatores dados ao sabor do acaso, a partir de encontros e conexões fortuitas que restam por ser descobertas. Essa discussão, resgatada por Deleuze em diversos momentos de sua obra, permite ao autor de O que é a filosofia? trabalhar com as tradicionais questões de fundamentação, normalmente abarcando a construção "o que é", em termos de potência e afetos e não mais de fundamentos.

O que é, doravante, significa pensar um determinado estado de coisas, não em termos de adequação em relação a uma ideia suprassensível, mas - e Deleuze lança mão de Espinosa para forjar com maior precisão seu argumento - em sondar as forças que atravessam esse mesmo estado. As coisas são, em determinado momento, uma resultante do embate entre forças distintas - instintos, instituições, discursos etc. Ao se descobrir como algo se torna aquilo que é, por conseguinte, passa-se a vislumbrar as possibilidades de se jogar com as forças que condicionaram esse objeto, permitindo, assim, desfazer certas conexões e tramar outras mais potentes. Em O que é a filosofia?, por conseguinte, não se lida com uma questão que busca examinar o ser primeiro da atividade filosófica, a essência dessa disciplina, 
mas sim que procura sondar os afetos possíveis no interior dessa atividade, concebida por Deleuze em termos de criação. Adentra-se em outro ambiente, como assinala o próprio filósofo em uma de suas aulas.

Suponham que eu diga que as diferenças entre uma mesa, um cavalo, um cachorro, uma menina e um menino, consistam unicamente no fato de não serem afetados pelas mesmas coisas. Em outras palavras, a diferença entre eles concerne somente aos seus poderes de serem afetados. Dito dessa maneira, parece pouco, mas, de uma forma estranha, as coisas, os animais, as pessoas, tendem a perder sua forma. Tudo bem se vocês me disserem que um cachorro é um mamífero, que tem quatro patas, ladra, e que um cavalo é uma outra coisa. Entretanto, entramos em um ambiente muito diferente quando afirmamos que aquilo que conta são os afetos dos quais alguém ou algo é capaz. Entramos em um bosque não conhecido. As coisas não se distinguem senão pelos afetos de que são capazes (DELEUZE, 2013, p. 278).

Adentrar nesse outro ambiente implica pensar o espaço de experiência não mais em termos de limitação, a partir de uma ideia suprassensível pretensamente responsável por ditar os seus limites formais, mas em termos de movimentos afetivos possíveis em seu interior, os graus de distensão ou contração que alguém ou algo é capaz de suportar em determinado agenciamento. Perguntar o que é um cão?, retomando o exemplo supracitado e encerrando por ora essa discussão, apenas serve para corroborar a imagem formal e dogmática que se tem desse animal. Mais interessante é pensar qual a potência de se adentrar em um devir-cão em dado momento, a fim de potencializar o viver. Tal indagação envolve uma radicalidade ímpar e implica estabelecer outra relação com o que significa pensar. Não mais buscar reconhecer ou enxergar o mundo em termos de padrões, presos àquilo que Deleuze (2006) denomina de uma imagem dogmática de pensamento, mas a busca pelo estabelecimento de conexões, tendo em vista os graus de potência afetiva passíveis de serem atingidos por um vivente (DELEUZE, 2013). Desse modo, resta indagar: é possível operar, nas pesquisas voltadas a discussões educacionais, com conceitos originados nessa outra ambiência? Dado o aumento da produção educacional inspirada pelo aparato conceitual de Deleuze-Guattari, conforme apontou-se alhures (referência omitida), justifica-se a importância e a urgência dessa interpelação. Este artigo procura discorrer não só acerca dessa outra ambiência, coligando-a com a atividade filosófica de criação conceitual, mas também esquadrinhar brevemente os modos de pesquisar de Deleuze e Guattari, compreendidos como vias de acesso privilegiadas para a compreensão do que significa habitar esse outro espaço entrevisto nesses autores. Tal discussão faz-se necessária, tendo em vista não apenas o aumento substância de trabalhos educacionais articulados com o pensamento deleuzeano e deleuze-guattariano, como também certos usos e abusos desse mesmo pensamento vislumbrados na área. 


\section{Usos (e abusos) do pensamento de Deleuze e Deleuze-Guattari no campo educacional}

Nas últimas décadas, aumentou substancialmente o número de artigos, teses e dissertações interessados em refletir temáticas educacionais a partir de uma interpelação deleuzeana e/ou deleuze-guattariana. Conforme notou-se alhures (referência omitida), esses estudos têm recebido uma acolhida cada vez maior dpor parte dos pesquisadores da área e têm incentivado discussões educacionais pouco ortodoxas. Conceitos como devir, rizoma, cartografia, e tantos outros, passaram a ser utilizados com frequência, e Deleuze e Deleuze-Guattari tornaram-se autores conhecidos por muitos. Mas qual a razão de tamanho interesse?

Conforme nota Silvio Gallo (2008), embora Deleuze - com ou sem seu parceiro, Guattari - jamais tenha se dedicado a escrever ou refletir sobre educação, sua obra traz interpelações relevantes e necessárias para aqueles interessados em discutir tópicos educacionais sob outro viés. Os pensadores franceses podem auxiliar muitos educadores e pesquisadores do campo a pensar a educação em termos afetivos, procurando sondar o que pode a educação hoje de um modo imanentista, ao invés de buscar referendar/julgar práticas educacionais a partir de um universo de valores suprassensíveis. Esse outro modo de pensar a educação possibilita pensar ou criar práticas educacionais que levem em conta apenas as relações imanentes vivenciadas por um indivíduo, ao invés de representações que ditam o que a educação deva ser.

Esse outro modo de interpelar a educação pressupõe produzir alguns deslocamentos. A partir dos afetos extraídos do aparato conceitual deleuzeano e deleuze-guattariano, dos modos singulares de sentir e pensar expressos por sua filosofia, muitos pesquisadores em educação procuram problematizar certas aporias presentes no campo, limitações que impedem de se criar essa dita educação. Acerca desse modo de operar com Deleuze e Deleuze-Guattari, Gallo comenta:

Penso que essa atividade [deslocar conceitos de Deleuze e Deleuze-Guattari para o campo educacional] pode ser bastante interessante e produtiva (em sentido deleuzeano), na medida em que esses conceitos passam a ser dispositivos, agenciamentos, intercessores para pensar os problemas educacionais, dispositivos para produzir diferenças e diferenciações no plano educacional, não como novos modismos, ou repito, o anúncio de novas verdades, que sempre nos paralisam, mas como abertura de possibilidades, incitação, incentivo à criação $(2008$, p. 54).

Em outras palavras, significa trabalhar em companhia de Deleuze e Deleuze-Guattari, sem tomá-los como mestres da verdade, mas como incitadores, autores que fornecem indagações potentes para se pensar a educação para além da representação. Para muitos pesquisadores do campo educacional, preocupados em tomar as obras dos pensadores 
franceses como intercessores, o mais importante é quebrar as verdades eternas impostas à área; os modos de sentir e pensar a educação pautados por valores transcendentes, contra qualquer finalismo e contra qualquer moralidade. $\mathrm{O}$ pensamento, nesse diapasão, deixa de ser da ordem da representação e passa a ser da ordem da invenção de outros possíveis e em busca da criação de outra educação (RIBEIRO, 2014).

Ilustra-se esse quadro supramencionado resgatando algumas publicações da área, de modo a se pensar como esse deslocamento tem sido trabalhado. Para tanto, citam-se alguns livros publicados recentemente, quais sejam: O oco do vento: metodologia da pesquisa sociopoética e estudos transculturais, de autoria de Jacques Gauthier; Filosofia: entre o ensino e a pesquisa, organizado por Carmelita Brito de Freitas Felício; Metodologias de pesquisa pós-críticas em educação, de Dagmar Estermann Meyer e Marlucy Alves Paraíso; Pistas do método da cartografia: pesquisaintervenção e produção de subjetividade, de Eduardo Passos, Virgínia Kastrup e Liliana da Escóssia; Pesquisar na diferença: um abecedário, de Tania Mara Galli Fonseca, Maria Lívia do Nascimento e Cleci Maraschin; e, por fim, Conexões: Deleuze e arte e ciência e acontecimento e..., organizado por Susana Oliveira Dias, Davina Marques e Antônio Carlos Amorim. O que dizem esses trabalhos?

No primeiro trabalho, $\mathbf{O}$ oco do vento, busca-se ofertar ao leitor um relato pessoal acerca do surgimento e desenvolvimento de uma metodologia de pesquisa, a sociopóetica (GAUTHIER, 2012); em outro, o intuito é organizar um abecedário "a partir de palavras propostas pelo próprio processo de pesquisar" (FONSECA, NASCIMENTO e MARASCHIN, 2012, p.9). Duas das obras supracitadas, ainda, focam-se em discutir questões teórico-metodológicas particulares (MEYER e MARLUCY, 2012; PASSOS, KASTRUP e ESCÓSIA, 2012); , enquanto outra opta por apresentar ensaios de formação mais abrangentes (FELÍCIO, 2012). Por fim, um dos livros compila os textos de um seminário que se propôs a ser antes um acontecimento do que um espaço de discussão, por meio da "suspensão da violência lógica de produção acadêmica atual" (DIAS, MARQUES e AMORIM, 2012, p. 10). Obras singulares, sem dúvida, mas que, devido ao interesse em articular o pensamento deleuze-guattariano, acabam por convergir em certos aspectos.

Em primeiro lugar, tratam-se de publicações em sua maioria ligadas a grupos de pesquisa ou seminários espalhados pelo país ${ }^{2}$. Os textos compilados nessas obras, portanto, procuram trazer a público os resultados de

\footnotetext{
2 Os grupos envolvidos nessas publicações são: Laboratório de Estudos Audiovisuais - Olho (FE-Unicamp); Diferenças e Subjetividades em Educação - DIS (FE-Unicamp); MultiTÃO: Prolifer-Arte Sub-Vertendo Ciências e Educações (Labjor-Unicamp); Kalos - Núcleo de Estudos e Pesquisa sobre o Ensino da Filosofia (UFG); Corpo, Arte e Clínica nos Modos de Trabalhar e Subjetivar (UFRGS); Pivetes - Programa de Intervenção Voltada às Engrenagens e Territórios de Exclusão Social (UFRGS); Geec - Grupo de Estudos e Pesquisa sobre Currículos e Culturas (UFMG); Geerge - Grupo de Pesquisa em Educação e Relações de Gênero (UFMG). Apenas duas obras não estão ligadas a grupos de pesquisa, diretamente ao menos. São elas: Pistas do método da cartografia, obra resultante de um seminário realizado por dois anos, na Universidade do Espírito Santo, e O oco do vento, escrita pelo criador do método da sociopoética, metodologia que conta com uma seara de adeptos na área educacional.
} 
pesquisas concluídas ou em andamento em certos departamentos. Além de consolidar uma experiência de pensamento levada a cabo pelos autores, tendo em vista os fins almejados pelos grupos/seminário. O grupo Kalos, por exemplo, responsável pelo livro Filosofia: entre o ensino e a pesquisa, tem como horizonte conferir um estatuto filosófico à discussão acerca do ensinar/aprender filosofia nas escolas de todo o país (FELÍCIO, 2012, p. 18). Já o grupo organizado em torno de Virgínia Kastrup e Eduardo Passos, assume como tarefa específica discutir os dez pontos que compõem o método cartográfico elaborado por Gilles Deleuze e Félix Guattari em Mil platôs e suas implicações nas pesquisas da área de saúde, psicologia e educação. Horizontes diferentes, envolvendo usos diversos dos textos deleuze-guattarianos. Os livros originados desses encontros acabam, assim, mais do que dar a conhecer os trabalhos desenvolvidos particularmente pelos seus integrantes, por balizar a posição de uma linha de pesquisa diante da considerável miríade de publicações que surgem todos os anos no mercado editorial. Além de compartilhar e afirmar certa experiência de pensamento, apresentada muitas vezes como inédita ou pouco explorada. Cada grupo, porém, opera um deslocamento singular.

Um segundo aspecto a se destacar é a atenção dispensada por essas obras às discussões teórico-metodológicas. Em sua maioria, os textos compilados nessas publicações propõem-se a discutir questões de método sob a ótica dos teóricos ditos pós-estruturalistas, mormente Gilles Deleuze e Félix Guattari, além de forjar/sugerir ferramentas analíticas para pesquisadores de áreas diversas.

Recusando ofertar uma ferramenta de pesquisa pronta, para que um pesquisador possa utilizar em seu trabalho como um tabulador o faria com uma fórmula matemática, as obras supracitadas visam a problematizar certos aspectos inerentes ao ato de pesquisar, conduzindo o leitor a pensar outros problemas - por meio da discussão de alguns conceitos-chave - e a elaborar outras perguntas. Não se trata de um auxílio, de um manual, mas de refletir sobre modos de problematização em conjunto com um leitor interessado. Portanto, a discussão teóricometodológica empreendida por essas obras visa a colocar em xeque as certezas daquele que se aventura por suas páginas, provocando um curto-circuito no leitor em vez de auxiliá-lo na busca da verdade. É um modo difícil de se trabalhar, mas em consonância com o pensamento deleuzeano e deleuze-guattariano, que recusa qualquer método.

Em todos os textos supramencionados, é possível observar uma procura pelo ato de experimentar, entendido tal como conceito proposto por Deleuze e Guattari: uma paixão pelo pensar que leva a recusar o binarismo ou a representação, formas de pensamento que implicam uma operação por meio da qual a mente cria para si a imagem de um objeto/essência exterior. Trata-se, portanto, de uma convocação dos pesquisadores da área para operarem um pensamento singular e ativo, capaz de gerar afecção, e não reflexivo. A experimentação é tomada, por esses autores do campo educacional, como forma de evitar o caráter contemplativo que orienta as pesquisas 
educacionais, em constante busca pela essência de um determinado problema. Experimentar é criar, intervir no real, mas sem recorrer a um alhures. Pode-se perceber que, em todas essas obras, há um procedimento analítico que lança mão de certos elementos da filosofia deleuze-guattariana, não para ofertar uma interpretação sobre tópicos educacionais, mas para afetar o leitor e operar um processo de dessubjetivação. Uma ascese, portanto (referência omitida).

Esses usos e abusos do pensamento de Deleuze e Deleuze-Guattari, porém, muitas vezes têm rendido obras de caráter duvidoso, como o notam alguns autores (MEYER e MARLUCY, 2012; PASSOS, KASTRUP e ESCÓSIA, 2012). Assim como qualquer outro pensamento, aquele de Deleuze e Deleuze-Guattari exige um estudo aprofundado de sua obra, um rigor analítico, não obstante seus conceitos incitarem a experimentações de muitas ordens. O problema é que a incitação radical inerente ao conceitual deleuzeano e deleuze-guattariano, muitas vezes, tem levado os pesquisadores a adotar palavras de ordem extraídas das obras desses autores como se fossem um conjunto de regras metafísicas. Por esse e por outros motivos, faz-se necessário trazer à baila uma discussão sobre o que significa operar com os conceitos deleuzeanos e deleuze-guattarianos, tão avessos a qualquer metafísica.

\section{A colocação de uma questão em um ambiente regido por potências e afetos}

Costumeiramente, os leitores de Deleuze e Guattari, interessados em educação, tendem a buscar conhecer nos conceitos deleuze-guattarianos seu sentido primeiro ou sua definição formal, a fim de facilitar a sua aplicação nesse campo. São demandas intelectivas a movê-los, sem sombra de dúvida. Compreender o que é rizoma, o que é devir, o que é corpo sem órgãos, e assim por diante, faz parte do cotidiano de pesquisa.EE, se assim é feito, é apenas em prol das potências virtuais que tais noções carregam consigo, capazes de abrir o campo de saber para outras conexões, quiçá mais potentes. O que é o devir?, nesse caso, talvez uma questão legítima, dependendo do problema com o qual se lida, conforme certo fim pedagógico ${ }^{3}$. Antes de seguir por essa vereda, convém notar que se encontram respostas satisfatórias para tais perguntas nas obras do próprio Deleuze, escritas ou não em parceria com Guattari. Por exemplo, acerca do devir, o filósofo responde:

\footnotetext{
3 Ou, pensando tratar-se de uma questão com fins pedagógicos, é legítima simplesmente por propiciar o aprendizado de certos conhecimentos empíricos necessários para os desdobramentos de uma pesquisa. Assim, a pergunta pode ser colocada da seguinte maneira: O que é o devir para Gilles Deleuze? O caráter pedagógico de questões envolvendo a ordem do gnosiológico, e sua relevância para aquisição de qualquer conhecimento particular, é postos por Deleuze em Diferença e repetição ( 2006).
} 
Devir nunca é imitar, nem fazer como, nem uma sujeição a um modelo, seja ele de justiça ou de verdade. Não há um termo de que se parte, nem um ao qual se chegue ou ao qual se deva chegar. Também não há dois termos intermutáveis. A questão "o que é que tu devéns" é particularmente estúpida. Porque à medida que alguém devém, aquilo que devém muda tanto quanto ele próprio. Os devires não são fenômenos de imitação, nem de assimilação, mas de dupla captura, de evolução não-paralela, de núpcias de dois reinos (DELEUZE e PARNET, 2004, p. 12). ${ }^{4}$

Pode-se ler essa afirmação em uma chave metafísica - e, muitas vezes, isso é feito sem ser percebido. O risco, nesses casos, é tomar tal definição como uma ideia reguladora do que seja o devir, impedindo que se estabeleça uma conexão potente e sem apriorismos entre tal noção e o problema de pesquisa e transmutando o princípio plástico que pretensamente rege o dispositivo conceitual deleuze-guattariano em um fundamento metafísico apenas. Para evitar tal armadilha, costumeiramente prende-se à definição da filosofia como gesto criativo, como se, o ato de enunciar que se fala de um local criativo, por si, pudesse apaziguar os deslizes cometidos na apropriação conceitual de DeleuzeGuattari. Em primeiro lugar, os pesquisadores em educação têm de lembrar que a criação conceitual compete somente à filosofia. Cabe aos pesquisadores em educação criar conceitos? Talvez sim, mas, como pedagogos, educadores ou, simplesmente, pesquisadores em educação, a meta inicial talvez seja outra ${ }^{5}$. Abonada essa questão, não se pode negar que o deslocamento de conceitos criados pela filosofia, como aqueles elaborados pela dupla Deleuze-Guattari, para o campo das pesquisas educacionais, têm ajudado muitos pesquisadores da área na problematização de seu campo. Para os fins propostos deste artigo, apenas salienta-se a necessidade de se compreender um conceito, mais do que possuidor de certa essência, como fruto de um trabalho inventivo, realizado em concomitância à colocação/invenção de certos problemas ${ }^{6}$, tal qual defendem Deleuze e Guattari em O que é a filosofia? (1992).

${ }_{4}$ Em Mil platôs, depara-se com a seguinte construção: "Um devir não é uma correspondência de relações. Mas tampouco é ele uma semelhança, uma imitação e, em última instância, uma identificação. Toda a crítica estruturalista da série parece inevitável. Devir não é progredir nem regredir segundo uma série. E sobretudo devir não se faz na imaginação, mesmo quando a imaginação atinge o nível cósmico ou dinâmico mais elevado, como em Jung ou Bachelard. Os devires-animais não são sonhos nem fantasmas. Eles são perfeitamente reais. Mas de que realidade se trata? Pois se o devir-animal não consiste em se fazer de animal ou imitá-lo, é evidente também que o homem não se torna 'realmente' animal, como tampouco o animal se torna 'realmente' outra coisa. O devir não produz outra coisa senão ele próprio" (DELEUZE e GUATTARI, 2008, p. 18).

5 A discussão acerca do que compete à educação criar é uma constante na produção educacional inspirada por Deleuze-Guattari. Sobre as questõnes abordadas por essa vertente, remete-se o leitor a (referência omitida).

${ }^{6}$ Nesse sentido, como o nota Eladio Craia (2002), o falso e o verdadeiro não dizem respeito às soluções que um problema comporta, mas ao problema em si. O quanto este permite ou não criar, ou pode um determinado problema produzir pensamento? "Toda verdade e falsidade são produzidas a partir da estrutura interna do problema a qual se desdobra nos registros empíricos, e não mediante a obtenção de uma possível resolução do próprio problema que provasse a sua consistência e valor" (CRAIA, 2002, p. 133). 
A elaboração de um conceito parece demandar experimentação mais do que compreensão. Não são os conceitos prontos que interessam a Deleuze, mas sim aqueles inventados ou disparados quando do encontro com um signo que o violenta e o leva a pensar ${ }^{7}$. Entretanto, nada impede, e Deleuze-Guattari parecem inclusive incitar a isso, que se tomem tais definições numa chave intelectiva apenas, como se fossem noções prontas - o excerto supramencionado assim o comprova. Como isso funciona?

O desdobramento dessa questão pode explicar muitas das confusões envolvendo certas apropriações da filosofia da diferença deleuze-guattariana, sobretudo quando essas assimilações ocorrem de maneira automática ou, como argumenta Luiz B. Orlandi (2000), pouco atentas àquilo denominado pelo comentador de composição elementar dos encontros. Esta implica uma aliança entre interesse vital, aquilo que se denomina alhures (referência omitida) de experimentação e compreensão intelectiva. Mesmo que seja necessário inventar os próprios conceitos, essa atividade só é possível quando da colocação de um problema, também ele inventado. Problema e conceito confundem-se no processo inventivo. Se assim o é, qual seria o grande disparador? Como resposta imediata, pode-se afirmar ser aquele dito encontro com um signo capaz de violentar. Colocado dessa forma, de maneira hermética, pode-se enveredar para a construção de uma leitura estrutural do pensamento de Deleuze e DeleuzeGuattari, e este não é o caso aqui. Acredita-se que os conceitos deleuzeanos e deleuze-guattarianos comportam, sim, um outro possível capaz de ser apreendido de maneira exegética apenas. Isto é, pode-se apreender o que é um devir apenas tomando como base o que dizem os autores; porém, a atualização desse conceito, ou sua concretização no real, ocorre apenas quando se entrega a uma experimentação radical do mesmo. Lidar com o dispositivo conceitual elaborado por Deleuze e Guattari demanda um trabalho capaz de possibilitar a compreensão da especificidade de seus conceitos. Ao mesmo tempo, proporciona sua experimentação, conectando-os a outros agenciamentos a fim de extrair-lhes - ou atualizar - a sua potência virtual ${ }^{8}$. Ou, em outros termos, exige que se habite em um mundo regido por potências e afetos. Para tanto, convém conciliar as experimentações radicais com certa dose de prudência, como os próprios autores defendem em alguns momentos de sua obra (DELEUZE e GUATTARI, 2007).

\footnotetext{
7 Para Deleuze, o pensamento não é algo inato, mas fruto de uma violência derivada do encontro com um signo. Essa discussão, provavelmente conhecida dos leitores de Deleuze e Guattari, pode ser encontrada mais bem formatada em obras como Diferença e repetição e, sobretudo, Proust e os signos.

8 Para Deleuze, atual e virtual não possuem qualquer hierarquia ou relação metafísica. Ambos os termos convivem naquilo que o autor denomina de plano de imanência, e estão numa relação de troca perpétua. Sobre a discussão do estatuto do atual e do virtual, e sua relação, ver Deleuze (1996).
} 
Sintetizando a hipótese desenvolvida até o presente momento: os conceitos deleuze-guattarianos parecem possuir um dinamismo próprio, a noção de devir assim o atesta, cuja força reside no fato de serem forjados tanto para experimentações de pensamento quanto para apreensões intelectivas. Parece relevante retomar essa discussão na medida em que muitas das apropriações do aparato conceitual deleuze-guattariano vivem na iminência de transmutar certos conceitos de Deleuze-Guattari em fórmulas estáticas, destituídas de potência - não obstante muitos pesquisadores justificarem seu flerte com esses autores, almejando potencializar o seu campo de saber. Não se trata, contudo, de criar um parâmetro para avaliação do quão deleuze-guattarianos ou não os pesquisadores brasileiros em educação têm sido. Mas, dado o aumento dessa produção no campo das ciências humanas, mormente na área educacional (referência omitida), buscar atentar e ressaltar certa especificidade do aparato conceitual de Deleuze e Guattari a fim de que se possa trabalhar com eles e não apenas a partir deles. Compreensão ou experimentação? Para que serve um conceito afinal? Como, a partir de determinadas criações conceituais, passar a habitar aquela outra ambiência de pesquisa, regida por afetos?

\section{Um conceito: para que serve?}

Gilles Deleuze e Félix Guattari, em seu derradeiro escrito conjunto, O que é a filosofia?, fornecem uma definição formal do que são os conceitos. Para os autores, seriam multiplicidades, constituídas e definidas por um número finito de componentes. O cogito cartesiano, seguindo um exemplo dado pelos autores, define-se pela multiplicidade "eu penso, logo eu sou", ou seja, é constituído pela junção de três componentes: duvidar, pensar e eu. De onde estes teriam sido retirados? Deleuze e Guattari (1992) esclarecem que tais componentes nada mais são do que recortes de virtualidades outrora esparsas no caos, inseridos pelo filósofo em um plano que dá consistência a essa operação, o denominado plano de imanência, e por meio de uma figura peculiar, o personagem conceitual. Por qual razão um conceito recorta determinados componentes e não outros? Ora, devido ao problema específico colocado pelo filósofo. Criação conceitual e colocação de problemas estão interligados, conforme o nota Fernando Tôrres Pacheco (2013, p. 20-37):

A criação de conceitos é uma pressuposição recíproca; ela só faz sentido ao se interligar a um problema. Todo conceito reporta-se a um problema sem o qual não teria propósito de existir, do que decorre que só podem ser circunscritos e abarcados juntamente à sua solução, às suas respostas. (...) Somente quando nos defrontamos com problemas que requerem conceitos que os resolvam é que o pensamento sai do seu estágio de indiferença. 
Os problemas, entretanto, e aqui se afasta da análise de Pacheco, não estariam postos no mundo, pelo contrário. Não se depara com um ou com outro problema que demanda uma determinada solução, mas inventa-se um problema concomitantemente ao conceito que o "resolveria". Depara-se com uma "experimentação tateante" (DELEUZE e GUATTARI, 1992, p.59), na qual a experiência é levada a um limite no qual resta ao pensamento apenas engendrar a si próprio, sem recorrer a qualquer a priori. Esse movimento, no qual condicionado e condicionante coincidem, outrora fora denominado por Deleuze de empirismo transcendental. Experimenta-se, ou cria-se, um estado de coisas a fim de extrair não o já sabido, ou criar um campo propício para a aplicação de um conceito preexistente, mas atualizar outro e virtual campo de possíveis.

Essa discussão, deveras formal, é conhecida por muitos daqueles interessados na filosofia da diferença de Deleuze-Guattari. Contudo, apresentada dessa maneira um tanto sumária e beirando o banal, pode gerar certas confusões. Ora, o conceito não é nada além de uma tentativa, singular, diga-se de passagem, de solução de um problema inventado por um pensador. De fato, assim o é, mas o que demandou essa escolha de percurso? E, ainda, estaria o conceito limitado a resolver um problema apenas, ainda que inventado? A resposta para essas questões já não é tão simples, sobretudo devido ao fato de que livrar-se dos problemas colocados é algo deveras radical, por implicar a saída de um "estado de escravidão" (DELEUZE, 2012, p. 11).

Inventar um problema envolve uma "verdadeira liberdade", conforme se discutiu acima, e por qual razão? Em um texto escrito em homenagem a Maurice de Gandillac, intitulado Praias de imanência - traduzido para o português no jornal Folha de S. Paulo9 -, Gilles Deleuze defende que "os conceitos filosóficos, para quem os inventa ou esclarece, são também modos de vida e de atividade" (2003, p.245). Tal definição, muito diferente daquela mais tradicional ofertada no livro escrito em parceria com Félix Guattari, O que é a filosofia?, tem a vantagem de explicitar outra faceta da noção de conceito. A invenção conceitual comporta o invento de outros modos de vida. Portanto, ao se criar um problema, e um determinado conceito, procura-se inventar novas maneiras de agir e pensar, mais potentes, ou seja, colocar-se na contracorrente dos modos de vida vigentes. Contra a vida ordinária, a vida filosófica ${ }^{10}$.

Há, portanto, uma íntima ligação entre a invenção de uma filosofia, a atividade de criação conceitual e a de uma vida filosófica. Deleuze e Guattari chegaram a comentar acerca desse tópico, valendo-se da obra de Nietzsche:

9 Sobre a importância da circulação midiática dos textos e do aparato conceitual de Deleuze-Guattari para as pesquisas acadêmicas brasileiras, remete-se o leitor a (referência omitida).

${ }^{10}$ A ideia de uma vida filosófica procede da leitura deleuzeana da obra de Spinoza (DELEUZE, 2002). Trabalhou-se outrora com essa questão. 
Nietzsche dizia que a filosofia inventa modos de existência ou possibilidades de vida. É por isso que bastam algumas anedotas vitais para fazer o retrato de uma filosofia, como Diógenes Laércio soube fazê-lo escrevendo o livro de cabeceira ou a lenda dourada dos filósofos. Empédocles e seu vulcão, Diógenes e seu tonel. Objetar-se-á a vida muito burguesa da maioria dos filósofos modernos; mas a liga de meias de Kant não é uma anedota vital adequada ao sistema da Razão? E o gosto de Espinoza pelos combates de aranhas deriva do fato de que reproduzem, de maneira pura, relações de modos no sistema da ética entendida como etologia superior. E que estas anedotas não remetem simplesmente a um tipo social ou mesmo psicológico de um filósofo (o príncipe Empédocles ou o escravo Diógenes), elas manifestam, antes, os personagens conceituais que o habitam. As possibilidades de vida ou os modos de existência não podem inventar-se, senão sobre um plano de imanência que desenvolve a potência de personagens conceituais (1992, p. 96-97).

Destarte, mais do que, formalmente, propiciar um recorte do caos, um conceito deve também ser capaz de dar suporte à invenção de novas possibilidades de vida. Percebe-se aqui que Deleuze e Guattari concebem o conceito como comportando duas faces: uma formal, interessada nas "camadas de realidade que constituem um ser" (DELEUZE, 1968, p. 55); e outra modal, referindo-se às variações de intensidade de que um conceito seria capaz de fomentar. Um conceito possui lastros ontológicos, por propiciar no ato de sua criação outra possibilidade de vida, o rearranjo de um estado de coisas. Desse modo, pode-se falar que determinado conceito é, uma vez que possui distinção formal, mas isso não significa que Deleuze-Guattari coadunam com uma lógica metafísica. Isso porque o elemento modal inerente ao conceito demanda uma experimentação do mesmo, e esta, incapaz de ser determinada a priori, é a única capaz de atualizar aquilo que um conceito pode.

Essa constatação, ainda formal em demasia, embora auxilie na compreensão do quão revolucionária é a atividade criativa tipicamente filosófica, a criação de conceitos, tende a engessar a potência envolvida nessa atividade. Para ilustrar o caráter radical da criação de conceitos deleuze-guattariano, convém recorrer ao percurso intelectual da dupla de autores, trazer à baila a narrativa de uma experimentação de pensamento em ato. Que se trabalhe, pois, com um exemplo e que se busque pensar, a partir do modo de trabalho de Deleuze-Guattari, como os conceitos criados pelos autores tornaram-se aquilo que são.

\section{Gilles Deleuze \& Félix Guattari: uma experimentação do pensamento}

Certa vez, em conversa com Claire Parnet, Gilles Deleuze comentou: 
Eu tentava nos meus livros precedentes descrever um certo exercício do pensamento. Mas descrevê-lo não era ainda exercer o pensamento desse modo. (Analogamente, gritar "viva o múltiplo" não é ainda fazê-lo, é preciso fazer o múltiplo. E também não basta dizer "abaixo os gêneros", é preciso escrever efetivamente de tal modo que já não existam "gêneros", etc.). Eis que, com Félix, tudo isso se tornava possível, mesmo que falhássemos (DELEUZE e PARNET, 2004, p. 27-28).

$\mathrm{O}$ excerto em questão aponta para uma interessante distinção entre descrever e exercer um pensamento. De acordo com Deleuze, seus livros escritos antes de $\mathrm{O}$ anti-Édipo primaram por certa descrição de outro exercício de pensamento, contraposto àquilo que o autor denomina imagem de pensamento dogmática. De acordo com o filósofo francês, foi Friedrich Nietzsche quem primeiro adentrou nessa batalha, ao tomar como inimigas noções derivadas do bom senso e do senso comum e ao atrelar o pensamento às categorias de sentido e de valor. O filósofo alemão buscou inspirar um modo de pensar capaz de afirmar a vida, de potencializá-la em prol da criação de outros valores. Para tanto, realizou uma grande crítica à cultura de seu tempo, domesticadora de nossos institutos primeiros, e às verdades estabelecidas, demonstrando serem estas meras construções. Vê-se surgir nas obras do pensador alemão uma nova imagem do pensamento, na qual este deixa de ser uma espécie de propensão natural do homem em busca da verdade primeira, passando a ser resultado de um violento efeito de forças.

Pensar designa a atividade de pensamento: mas o pensamento tem suas maneiras próprias de ser inativo, ele pode empenhar-se nisso inteiramente e com todas as suas forças (...). É preciso que uma violência se exerça sobre ele enquanto pensamento, é preciso que um poder force-o a pensar, lance-o num devir-ativo (DELEUZE, 1976, p. 88-89).

Encontra-se em Nietzsche uma das bases do projeto deleuzeano, cujo programa atinge sua forma mais bemacabada - de acordo com o próprio Deleuze - com os livros Diferença e repetição e Lógica do sentido, publicados, respectivamente, em 1968 e 1969,; e radicaliza-se nas obras escritas com Félix Guattari. É interessante notar como, guardadas as devidas proporções, o filósofo francês vai urdindo seu projeto, retomando certas discussões, ultrapassando-as e radicalizando-as. Por exemplo, nos escritos publicados na década de 1960, ele não procura mais uma nova imagem do pensamento, seguindo o próprio Nietzsche, mas um pensamento sem imagem e, posteriormente, transmuta essa busca em uma noologia, esta compreendida como "o estudo das imagens do pensamento e de sua historicidade" (DELEUZE e GUATTARI, 1997, p.46). Entretanto, não obstante todos esses movimentos no interior de seu pensamento, Deleuze ainda se encontra atrelado a um movimento descritivo, no qual arma as suas balizas 
teóricas. A verdadeira experimentação ocorre somente com a radicalização oriunda de sua parceria com Guattari, como fica claro no diálogo travado com Claire Parnet.

Esse exercício lançado a cabo pelos autores de Mil platôs caracterizou-se por uma radicalização da própria escrita, mas não é a escrita conjunta de Deleuze-Guattari propriamente que atesta a experimentação radical de pensamento conduzida pela dupla. Mas, sim, a urgência da empreitada levada a cabo pelos autores. Essa urgência é a grande disparadora do pensamento, ou o signo que os força a pensar. Buscar sondar tal urgência implicou colocar uma questão, inventar um problema e criar um conceito capaz de resolvê-lo. Sobre a questão da urgência, Deleuze argumenta em um texto intitulado $\mathrm{O}$ ato de criação:

Nos personagens de Dostoiévski, produz-se muitas vezes algo bastante curioso, que pode dizer respeito a um pequeno detalhe. Geralmente, eles são muito agitados. Um personagem sai de casa, desce até a rua e diz: "Tânia, a mulher que amo, me pede ajuda. Vou correndo, ela morrerá se eu não for". Ele desce a escada e encontra um amigo, ou vê um cão atropelado, e esquece, esquece completamente que Tânia o espera, à beira da morte. Ele se põe a falar, cruza com outro camarada, vai até sua casa tomar chá e, de súbito, diz novamente: "Tânia me espera, é preciso que eu vá". O que significa tudo isso? Em Dostoiévski, os personagens são perpetuamente vítimas da urgência e, ao mesmo tempo em que eles são vítimas dessas urgências, que são questões de vida ou morte, eles sabem que há uma questão ainda mais urgente, embora não saibam qual. E é isso que os paralisa. Tudo se passa como se, na maior urgência - "É um incêndio, é preciso que eu vá" -, eles se dissessem: "Não, existe algo ainda mais urgente. Não moverei um dedo até saber do que se trata". É "O Idiota" (romance de Dostoiévski filmado por Kurosawa). É a fórmula de "O Idiota": "Veja, há um problema mais profundo. Qual problema, não saberia dizer ao certo. Mas me deixe. Tudo pode arder... É preciso encontrar esse problema mais urgente" (1999, p. 8).

Uma urgência que não se conhece, mas cujos efeitos são prontamente sentidos. Elemento capaz de modificar uma atividade ou um estado de coisas. Pode-se objetar que se defende haver uma ausência de urgência nas obras monográficas de Deleuze, mas não é isso. Deleuze constrói os seus problemas, porém prolonga a urgência de certa linha filosófica para lhes fazer frente: Bergson, Nietzsche, Spinoza etc. Com Guattari, as urgências são outras e mais imediatas: O anti-Édipo e o discurso psicanalítico, Kafka: por uma literatura menor e os limites da crítica e por aí afora. A imagem de pensamento dogmática, apresentada pela primeira vez em Nietzsche é a filosofia, é uma questão urgente, envolve questões de vida e de morte, e impele Deleuze a pensar e buscar outra imagem ou um pensamento sem imagem; mas, eis que surge Guattari, e algo ainda mais urgente aparece. Os problemas trabalhados até então 
não são deixados de lado, mas postos a serviço da busca ou da invenção desse algo ainda mais urgente vivenciado no encontro Deleuze-Guattari.

Atentar para esse movimento é importante na medida em que possibilita vislumbrar a falácia em tomar o aparato conceitual deleuze-guattariano em uma chave metafísica. Não há fundamento que resista às variações conceituais presentes na obra da dupla de autores, tomadas ou não individualmente. As repetições dos conceitos, suas reformulações ou redefinições apenas contribuem para as modificações de ordem qualitativa operadas no interior destes. De Empirismo e subjetividade até O que é a filosofia?, o que se pode observar é uma experimentação tateante, rearranjos estratégicos capazes de evitar a estruturação de uma doutrina. Não obstante isso, por vezes, opera-se com o conceitual elaborado pela dupla de autores de maneira metafísica, sem atentar para esse princípio plástico que carregam ou, em outras palavras, sem experimentá-los. A composição elementar dos encontros, defendida por Orlandi (2000), nada mais é do que a compreensão da urgência que moveu Deleuze, demandando as tantas experimentações por parte do autor, aliada à busca ou à construção das próprias urgências, as questões vitais.

\section{Considerações finais}

Faz-se necessário encerrar fazendo um balanço da discussão empreendida até o presente momento. Apresentada de maneira um tanto hermética, diga-se de passagem, não teria justamente esgotado o dinamismo do conceitual deleuze-guattariano que tanto se frisou? Talvez assim o seja, mas o interesse principal, mais do que encerrar uma discussão ou operar certos conceitos deleuze-guattarianos, reside na busca por problematizar algumas apropriações dos conceitos elaborados por Deleuze e Guattari vislumbradas no campo das pesquisas educacionais. Mais do que os conceitos, a preocupação é trazer à baila o modo de pesquisar elaborado pela dupla de autores, ressaltar as experimentações levadas a cabo por Deleuze e Deleuze-Guattari para se perceber a especificidade do seu aparato conceitual. Este criado em meio à tensão entre a incitação às experimentações radicais e a exigência de certa prudência, a demanda por uma composição elementar dos encontros. Trata-se, acredita-se, de outra ambiência de pensamento, regida por afetos.

Ora, este trabalho atende a uma demanda intelectiva que poderia ser interessante para aqueles pesquisadores do campo educacional preocupados em operar com as fórmulas dos autores de Mil platôs sem cair em um dogmatismo deleuze-guattariano. Serve ainda para se aprofundar uma distinção importante para a pesquisa que se está empreendendo no momento, envolvendo a relação entre fórmula e procedimento no interior do pensamento de Deleuze e Guattari e suas implicações para os estudos do campo educacional, qual seja: a distinção entre interesse vital e interesse intelectivo. Ambos os interesses são discutidos por Henri Bergson e retomados por Deleuze (2012) 
em seu estudo sobre esse autor, e acredita-se, que tenham influenciado sobremaneira o projeto filosófico deleuzeano, ainda que de maneira indireta. Este trabalho em específico segue um interesse intelectivo, mas sem grandes intuitos experimentais. Pode-se ter radicalizado aqui ou acolá, mas não se acredita que a experimentação defendida por Deleuze e Guattari seja dessa ordem, embora muitos trabalhos delezeanos ou deleuze-guattarianos em educação primem por uma linguagem mais próxima da literária e pela radicalidade vocabular.

Por vezes, depara-se com trabalhos educacionais portadores de uma linguagem inovadora, carregados de neologismos e palavras-de-ordem deleuze-guattarianas, beirando o ensaio e interessados em estabelecer conexões autoproclamadas aberrantes. Seria essa a experimentação defendida pelos autores de Mil latôs? Não se sabe. De qualquer modo, deve-se lembrar que, mesmo a experiência mais radical, demanda certa prudência:

Mas por que este desfile lúgubre de corpos costurados, vitrificados, catatonizados, aspirados, posto que o CsO é também plano de alegria, de êxtase, de dança? Então, por que estes exemplos? Por que é necessário passar por eles? Corpos esvaziados em lugar de plenos. Que aconteceu? Você agiu com a prudência necessária? Não digo sabedoria, mas prudência como dose, como regra imanente à experimentação: injeções de prudência. Muitos são derrotados nesta batalha. Será tão triste e perigoso não mais suportar os olhos para ver, os pulmões para respirar, a boca para engolir, a língua para falar, o cérebro para pensar, o ânus e a laringe, a cabeça e as pernas? Por que não caminhar com a cabeça, cantar com o sinus, ver com a pele, respirar com o ventre, Coisa simples, Entidade, Corpo pleno, Viagem imóvel, Anorexia, Visão cutânea, Yoga, Krishna, Love, Experimentação. Onde a psicanálise diz: Pare, reencontre o eu, seria preciso dizer: vamos mais longe, não encontramos ainda nosso $\mathrm{CsO}$, não desfizemos ainda suficientemente nosso eu. Substituir a anamnese pelo esquecimento, a interpretação pela experimentação. Encontre seu corpo sem órgãos, saiba fazê-lo, é uma questão de vida ou de morte, de juventude e de velhice, de tristeza e de alegria. É aí que tudo se decide (DELEUZE e GUATTARI, 2007, p. 11).

"Encontre seu corpo sem órgãos, saiba fazê-lo", diz Deleuze e Guattari. Pois bem, experimentar não é apenas uma questão de radicalidade, mas também uma questão de conhecimento e prudência. A radicalidade é exigida de acordo com a urgência, ensejando a experimentação de um par questão-problema inventado. A prudência, contudo, exige conhecer, sondar os agenciamentos nos quais se adentra e as ferramentas com que se opera, os conceitos capazes de propiciar outro modo de agir e pensar. Interesse vital, a urgência, e interesse intelectivo, a prudência. Não se trata, contudo, de uma estrutura, essas noções são indeterminadas, tomam corpo à medida que são experimentadas dentro de um agenciamento concreto. Não há qualquer apriorismo, apenas uma arte capaz de ensaiar aquela composição elementar dos encontros, algo como estar aberto aos fluxos e aos signos. Por fim, trata-se de ressaltar as questões 
deleuze-guattarianas por excelência: qual a dose de prudência e a experimentação empreendida por um pesquisador diante de um determinado problema? Qual a vida que pulsa em suas linhas, quais conexões estabelece?

Deslocá-las para o campo educacional, tal qual defende Gallo (2008), pode ser um modo de permitir aos pesquisadores da área criar linhas de pensamento potentes, capazes de abrir a educação para outros possíveis. Para tanto, porém, é necessário compreender como a incitação radical inerente ao aparato conceitual de Deleuze e DeleuzeGuattari não prescinde de uma prudência metodológica, conforme notaram alguns autores (MEYER e PARAÍSO, 2012) e conforme se defende ao longo deste artigo. Sem essa compreensão, muitos trabalhos podem assumir tons caricatos e apresentar reflexões extremamente pobres, ou, o mais comum, acabar transmutando os conceitos da dupla de pensadores franceses em outra metafísica. Deleuze e Guattari não são autores preocupados em estabelecer novos valores, capazes de fazer com que se julgue de outro modo a educação, mas pensadores engajados na busca por fomentar outra sensibilidade, capaz de fazer com que se vislumbrem outros problemas e, assim, criando outros caminhos. Por esse motivo, mais do que nunca, faz-se necessário atentar para a ambiência de pesquisa singular propiciada pelo aparato conceitual deleuzeano e deleuze-guattariano. Sua importância para a pesquisa em educação não pode ser desconsiderada.

\section{Referências}

CRAIA, Eladio. A problemática ontológica em Gilles Deleuze. Cascavel: Edunioeste, 2002.

DELEUZE, Gilles. Bergsonismo. São Paulo: Editora 34, 2012.

. Derrames entre el capitalismo y la esquizofrenia. Buenos Aires: Cactus, 2013.

Deux eégimes de fous. Paris: Éditions de Minuit, 2003.

Diferença e repetição. São Paulo: Graal, 2006.

. Nietzsche e a filosofia. Rio de Janeiro: Taurus Editora, 1976.

. O ato de criação. In: Folha de São Paulo, Caderno Mais!, 27 de junho de 1999, p. 6-9.

. O atual e o virtual. In: ALLIEZ, Eric. Deleuze filosofia virtual. São Paulo: Editora 34, 1996.

. Spinoza el le problème de l'expression. Paris: Éditions de Minuit, 1968.

. Spinoza: filosofia prática. São Paulo: Escuta, 2002.

DELEUZE, Gilles; GUATTARI, Félix. Mil platôs. São Paulo: Editora 34, 2007. Vol. 3.

. Mil platôs. São Paulo: Editora 34, 2008. Vol. 4.

Mil platôs. São Paulo: Editora 34, 1997. Vol. 5.

Educação Por Escrito, Porto Alegre, v. 8, n. 2, p. 189-208, jul.-dez. 2017 
DELEUZE, Gilles; GUATTARI, Félix. O que é a filosofia? São Paulo: Editora 34, 1992.

DELEUZE, Gilles; PARNET, Claire. Diálogos. Lisboa: Relógio D'água, 2004.

DESCOMBES, Vincent. Lo mismo y lo otro: cuarenta y cinco años de filosofia francesa (1933-1978). Madri: Catedra, 1998.

DIAS, Susana Oliveira; MARQUES, Davina; AMORIM, Antonio Carlos (Org.). Conexões: Deleuze e arte e ciência e acontecimento e... Petrópolis, RJ: De Petrus; Brasília, DF: CNPq/MCT; Campinas, SP: ALB, 2012.

FELÍCIO, Carmelita (Org.). Filosofia entre o ensino e a pesquisa: ensaios de formação. Goiás: Edições Ricochete, 2012.

GALLO, Silvio. Deleuze e a educação. Belo Horizonte: Autêntica, 2008.

GAUTHIER, Jacques. O oco do vento: metodologia de pesquisa sociopoética e estudos multiculturais. Curitiba: Editora CRV, 2012.

MEYER, Dagmar Estermann; PARAÍSO, Marlucy Alves (Org.). Metodologias de pesquisas pós-críticas em educação. Belo Horizonte: Mazza Edições, 2012.

NIETZSCHE, Friedrich. Ecce homo. São Paulo: Cia das Letras, 2004.

ORLANDI, Luiz. B. Linhas de ação da diferença. In: ALLIEZ, Eric (Org.). Gilles Deleuze: uma vida filosófica. São Paulo: Editora 34, 2000, p. 49-64.

PACHECO, Fernando Torres. Personagens conceituais: filosofia e arte em Deleuze. Belo Horizonte: Relicário Edições, 2013.

PASSOS, Eduardo; KASTRUP, Vírgina; ESCÓSSIA, Liliana da (Org.). Pistas do Método da Cartografia: pesquisa-intervenção e produção de subjetividades. Porto Alegre: Sulina, 2012.

RIBEIRO, Cintya Regina. 'Práticas de pensamento' e o debate curricular: contribuições a partir de Foucault-Cortázar. In: Pró-posições, Campinas, v. 25, n. 1, p. 219-237, 2014.

(Quatro referências omitidas para garantia de anonimato.)

Recebido em: junho/2017

Aceito em: outubro/2017

Endereço para correspondência:

Av. da Universidade, 308 - Butantã

05508-040 São Paulo, SP, Brasil

$<$ christian.guimaraes.vinci@gmail.com> 